\title{
Production of Koi Herpesvirus-Free Fish: Implementing Biosecurity Practices on a Working Koi Farm in South Africa
}

\author{
K. D. A. Huchzermeyer ${ }^{1}$ and P. A. Colly ${ }^{2}$ \\ ${ }^{1}$ Department of Paraclinical Sciences, Faculty of Veterinary Science, \\ University of Pretoria, South Africa \\ ${ }^{2}$ Department of Ichthyology and Fisheries Science, Rhodes University, \\ Grahamstown, South Africa
}

\begin{abstract}
Principles of biosecurity and disease surveillance long applied in the salmonid industries to produce certified disease-free stock can equally be applied to the production of koi herpesvirus-free koi, despite limitations in diagnostic ability to detect asymptomatic carrier fish. To ensure freedom from koi herpesvirus, there is a strong case for eradication of known infected broodstock. Maintaining a closed population of fish on a protected water source, adherence to strict biosecurity measures, and strategic sampling at a statistically relevant confidence level over a 2year period can provide the guarantees needed for sale of certified disease-free fish. Propagation of such fish offers new entrepreneurial opportunities and has resulted in at least one breeder in South Africa achieving export certification for markets in the European Union.
\end{abstract}

KEYWORDS Breeding, carp, certification, Cyprinus carpio, disease-free, KHV, koi herpesvirus

\section{Introduction}

In many parts of the world the culture of ornamental fish is an important aquaculture activity. For decades the ornamental fish industry has relied on rapid shipment of fish by air to all parts of the world. Except for minor

Address correspondence to K. D. A. Huchzermeyer, P.O. Box 951, Lydenburg 1120, South Africa. E-mail: aquavet@telkomsa.net 
health certification requirements, shipment of koi has until recently remained relatively unhindered. Koi has traditionally been a highly valued ornamental fish in Japan, and the popularity of koi keeping has since expanded to many parts of the world. Serious hobbyists and breeders show their fish at annual koi shows, and many fetch high prices when traded, driving a lucrative koi breeding and retail industry. The shipment by air of large numbers of koi between countries and continents and the frequent movement and mixing of fish populations within countries and regions has created the ideal mechanism for the spread of contagious disease (Aoki et al. 2007; Taylor et al. 2010).

Koi are the ornamental variety of the common carp, Cyprinus carpio, and as such are susceptible to the diseases of common carp. Asymptomatic carrier fish contribute to the spread of these diseases. International movement restrictions, implemented in many countries to counter the biosecurity risk posed by the disease spring viraemia of carp (SVC), have in some countries recently been extended to include koi herpesvirus disease (KHVD). The spread of these diseases through shipments of carp has been well documented. SVC, caused by Rhabdovirus carpio, is endemic in countries in Eastern Europe where the commercial culture of food carp has been an important traditional economic activity. In more recent years the disease has been reported from Brazil, the USA, China, and Canada (OIE 2015a). In 1998 a hitherto unknown highly contagious disease, subsequently identified as KHVD, broke out among koi in many parts of the world (Bretzinger et al. 1999; Walster 1999). The disease caused serious losses in valuable koi collections in South Africa and elsewhere, and die-offs in both captive and wild food carp populations have been reported from many parts of the world (Bergman et al. 2006; Cheng et al. 2011; Kurita et al. 2009; Pokorova et al. 2005; Sano et al. 2004; Sunarto et al. 2005; Way 2004).

As with other herpes viruses, an asymptomatic carrier state has been demonstrated for KHVD, and recrudescence may occur (Bergman et al. 2009; Eide et al. 2011; St-Hilaire et al. 2005). In South Africa practical diagnostic confirmation was limited to histopathology and detection of viral DNA by polymerase chain reaction (PCR). Prior to 2011, PCR techniques in use in South Africa were unable to identify carrier fish, and a negative PCR result from healthy fish could not rule out koi herpesvirus (KHV) infection. Reliable tests for virus isolation and antibody detection had been developed elsewhere (OIE 2015b; St-Hilaire et al. 2009) but were not available in South Africa.

Introduction of KHVD into naïve populations of koi has disastrous effects with serious market implications. Protection afforded by recently developed KHV vaccines may help reduce clinical KHVD, but persistence of infection in carrier fish, even if vaccinated, may have potential serious consequences where such fish are imported. The negative KHV status of a fish population is of vital importance to both the exporter and importer of 
koi. The practice of producing disease-free salmonids has long been the basis for the international trade of salmonid ova. Rigorous testing and surveillance of salmonid parent populations and adherence to strict biosecurity measures has allowed veterinary authorities to provide internationally accepted guarantees of freedom from specified salmonid diseases. Only a limited number of pathogens are known to be transmitted transovarially, and with specific testing of the parent population and effective disinfection of ova prior to shipping, salmonid ova have been safely shipped around the world for many decades. These principles, although seldom applied to ornamental fish, can be used to establish KHV-free populations of fish.

In contrast to KHVD, which is commonly diagnosed in South Africa in koi collections and among brood stock, SVC has never been diagnosed in this country. As South Africa has no active surveillance program, the disease status of fish from this country remains unknown. Fish emanating from South Africa pose a potential biosecurity risk to importing countries, resulting in constraints on farmers wishing to export koi. In this article we describe the practical implementation of a biosecurity program as proposed by the International Aquatic Veterinary Biosecurity Consortium (IAVBC) (Palić et al. 2015).

\section{Case History}

\section{Identifying and Prioritizing Hazards}

Imported broodfish of unknown disease status were introduced to a commercial koi farm in the lowveld of the Limpopo Province in South Africa during the early summer of 2004. A protracted power outage caused a serious elevation of ammonia levels in the recirculated systems housing the broodfish. Within days increasing morbidity and mortality ensued in some ponds despite a return to normal water quality. Serious mortalities followed among harvested fish. These were initially ascribed by the farmer to harvesting stress.

The epidemiological pattern of the outbreak and the clinical signs of gill necrosis (Figure 1) in a high percentage of diseased fish indicated the likelihood of a KHV outbreak. PCR examination of swabs taken from the gills of affected fish confirmed presence of KHV. Virus isolation ruled out SVC. Heavy parasitic infestations and presence of Flavobacterium columnare on the skin of the fish were regarded as secondary to the KHV infection, and no attempts at treatment were made.

The authors were approached to help rehabilitate the affected fish farm. At the time fish were being actively marketed from the farm via both wholesale and retail markets. Fish that had been sold in the period before the diagnosis of KHVD was made caused further disease outbreaks and mortality in koi populations into which they had been introduced. To avoid litigation, 


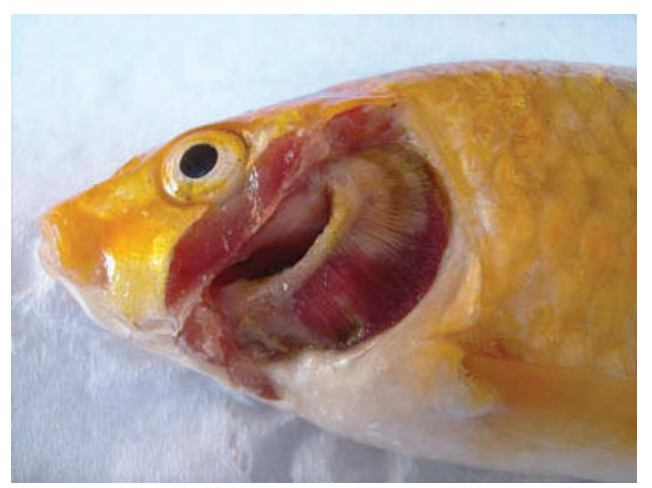

Figure 1 Typical gill necrosis in a KHV-infected koi.

the farmer had offered to replace customers' losses with healthy fish once the outbreak had been controlled.

\section{Assessing the Risk Impact of Potential Disease}

The farmer understood the implications of the disease relative to future marketing of fish from his farm, and he had previously indicated an interest in expanding his market to some European Union countries, especially the United Kingdom. This required certification of freedom from SVC, whereas the requirements for KHV certification at the time remained unclear. Considering the potential cost of producing disease-free fish, it was decided to follow the same certification procedure for both diseases.

The farm was situated within a dry subtropical area of South Africa, receiving only summer rainfall. Summer water temperatures exceeded $30^{\circ} \mathrm{C}$, masking clinical outbreaks of KHVD during a few months of the year. Fish that had survived the initial outbreak were potential carriers of KHV and were likely to shed virus, causing future disease outbreaks. The farmer agreed to destroy all fish on the farm except broodfish from ponds that had remained unaffected by the disease. Taking into consideration a possible carrier state, the retained fish were kept in designated broodfish ponds several kilometres away from grow-out ponds. In addition, both hatchery and grow-out ponds were disinfected with chlorine and lay dry for several weeks. The farming operation was divided into four discrete epidmiological areas: the broodfish facility, the hatchery, the earthen grow-out ponds, and the sorting and sale ponds. Each area was supplied by a separate water source. The grow-out ponds received only top-up water, whereas the sorting and sales ponds were on a recirculated water system with biofiltration.

To market large numbers of small juvenile koi, it is essential to provide a full range of color varieties. This requires maintaining a large variety of broodstock. The original broodstock variety had been seriously depleted 
by the KHV outbreak, and the KHV status of the surviving broodfish was uncertain. Certified disease-free sources from which to import new broodfish were not available at the time. The KHV status of newly imported, apparently healthy, replacement broodstock was therefore uncertain.

In order to rebuild its reputation, it was important for the farm to continue showing fish at the annual koi shows in South Africa and elsewhere. Viewed as a critical control point, this posed the risk of exposure to KHV from other fish and was discouraged. No broodfish were exhibited at shows. Only selected juvenile fish were taken to shows and subsequently sold. Fortunately, increased biosecurity awareness had led the South African Koi Keepers Association (SAKKS) to adopt the new European-style show format. Fish were no longer grouped in traditional communal show ponds. Instead each breeder or hobbyist had the exclusive use of one or more ponds for display, limiting the potential for spread of disease.

\section{Determining and Managing Possible Disease Introduction}

After destroying the potentially infected fish and disinfecting the ponds, the farmer imported a single new batch of broodstock from a reputable, but uncertified, source to add to the surviving broodfish. This presented the risk of reintroducing fish latently infected with KHV. The farm was put under regulatory control by the competent veterinary authority, and the farmer agreed to maintain a closed population of fish with new introductions only from sources with an equivalent or higher level of certification.

The closed water supply feeding the ponds originated from several boreholes. For short periods after heavy rainfall, an annual stream that traversed the farm carried water, but this was insufficient to sustain wild populations of fish. The entire property was fenced with access control, and workers were restricted from moving between potentially infected broodfish ponds and the noninfected grow-out and sale ponds that were situated several kilometers distant on the same property but within separately fenced areas. The earthen grow-out ponds covered an area of several hectares. Wires spanned overhead restricted access by birds. Vertically placed heavy-gauge plastic sheeting, buried along the perimeter of the ponds and extending approximately $40 \mathrm{~cm}$ above ground, was used to keep frogs out of the ponds. There were no goldfish on the farm.

All significant mortalities were reported and investigated by the authors. As consulting fish veterinarian, one of the authors met with the veterinarian representing the competent authority every 6 months to review the health records and biosecurity status of the operation.

A sampling strategy to detect disease in the hatchery was developed based on the $95 \%$ confidence level for detecting a disease with 2 percent prevalence in a population of fish exceeding 1,000 individuals (OIE 2015c). The hatchery protocol was, however, based on the assumption that vertical 


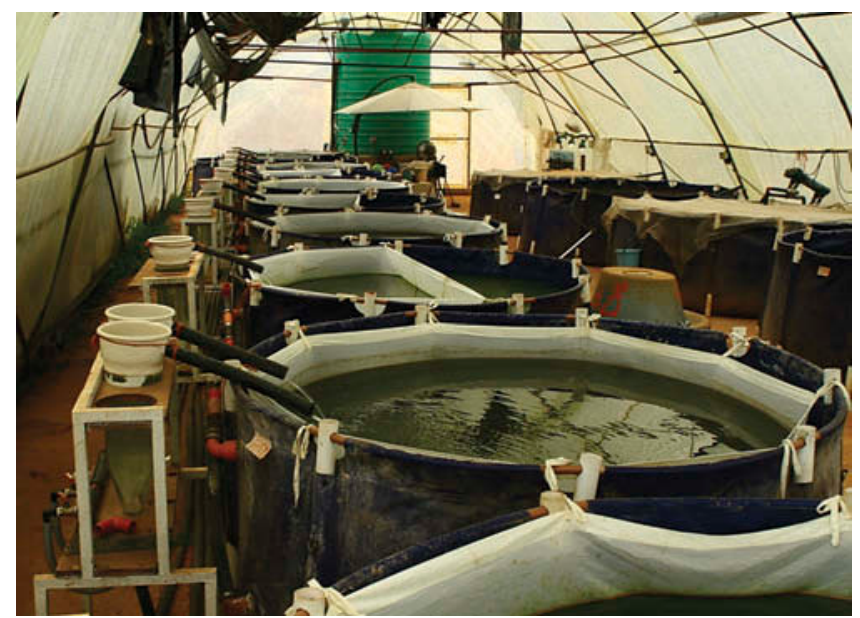

Fligure 2 Hatchery with Zoug jars and fry tanks on a recirculated water supply. Note that the tanks are within an enclosed plastic tunnel to maintain high water temperatures and to restrict access by birds. The fine-meshed nets within each tank held recently hatched fry that were being fed Artemia spp. nauplii. The hatchery ponds and equipment were routinely cleaned and disinfected with iodophore after the fry had been moved to the grow-out ponds.

transmission would not occur. Broodfish were artificially induced to spawn using a gonadotropin-releasing hormone (GnRH) analogue. Only healthy broodfish were selected for spawning. Excess water was dabbed off the fish with a moistened towel to prevent transfer of water or faecal material from broodfish to gametes. Ova and milt were stripped from broodfish into bowls. Once fertilized and water hardened, ova were disinfected with an iodophore disinfectant at $50 \mathrm{ppm}$ for $10 \mathrm{~min}$ and then incubated either on brushes or in Zoug jars (Figures 2 and 3). Fry were kept in the hatchery tanks and initially fed Artemia spp. nauplii before being released into recently filled and fertilized earthen grow-out ponds.

The farm maintained an annual production of koi fingerlings. The majority were sold before reaching 1 year of age. Broodfish were spawned in spring, and juvenile fish reached a marketable size by autumn. As the growout ponds were used on an all-in-all-out basis, the entire grow-out facility was fallowed, disinfected, and dried through the winter dry months.

\section{Diagnostic Testing and Disease Surveillance}

In order to activate potentially dormant KHV infections, the fish needed to be stressed before being transferred into water at the permissive temperature at which disease would be expected to manifest $\left(16^{\circ} \mathrm{C}\right.$ to $\left.25^{\circ} \mathrm{C}\right)$. Following draining of the earth production ponds, the harvested fish were transferred to cement sorting ponds. Here the fish were classed according to size and 


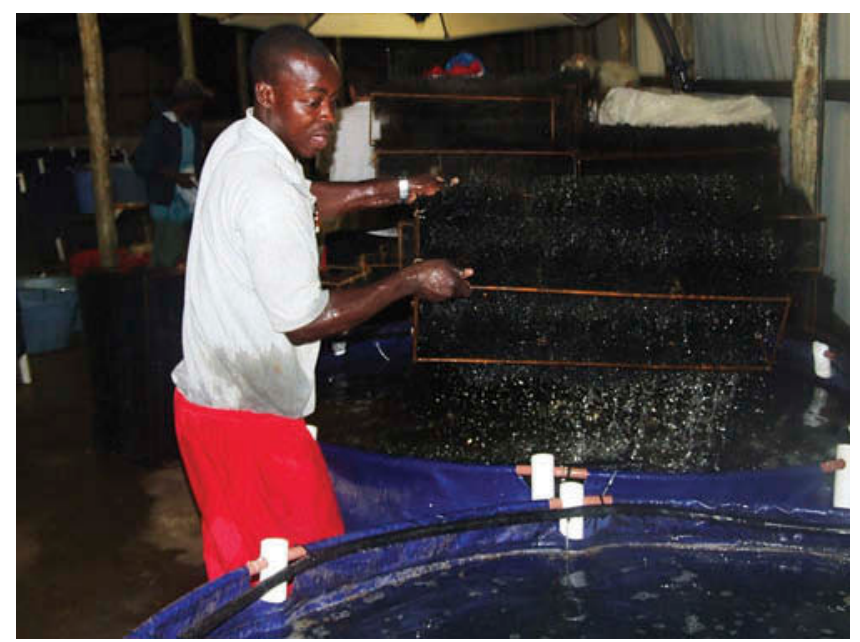

Figure 3 Water-hardened fertilized ova attached to brushes being moved to a tank containing iodophore disinfectant, an important hazard-control step. According to the hatchery protocol, the hatchery workers should be wearing protective clothing.

color prior to marketing. Every 6 months, during autumn and spring, 400 to 800 recently harvested cull fish (depending on size), from the current or most recent year's spawning, were held in cement sorting ponds for at least two weeks. Without prior food withholding, these fish were then packed into standard shipping bags with oxygen. Fish were kept in the bags for $6 \mathrm{~h}$ or longer, mimicking the harvesting and shipping stress normally associated with transport of koi. The fish were subsequently released into the authors' recirculated quarantine facility, where the fish were kept at the permissive temperature for KHV. The stresses of this procedure often led to parasitic and bacterial infection during the quarantine period.

Fish were kept in quarantine for a minimum of 14 days, after which 150 fish were sacrificed for sampling. Fish were euthanized using an overdose of benzocaine. Swabs collected from the gills of each fish were submitted to an accredited laboratory (Molecular Diagnostic Services, Durban, South Africa) for PCR testing for the presence of KHV DNA. Liver, spleen, and kidney were collected in phosphate-buffered saline especially prepared by the receiving laboratory for the transport of material for virus culture. The samples were submitted on ice to the Onderstepoort Veterinary Institute (OVI, Pretoria, South Africa) for SVC virus isolation on fish tissue cell lines. To mitigate the risk of resurgence of KHVD, the remaining original broodstock were removed from the farm over the following 2 years. The broodfish ponds were disinfected, and the broodfish were replaced with offspring from the tested population. To maintain export certification, the farm was subjected to continued veterinary inspections and 6-monthly sampling for disease testing. 


\section{Auditing and Veterinary Certification}

In order to export fish the farm was required to meet the registration requirements for export farms in South Africa. This required twice-yearly inspection of the facility by a designated fish disease veterinarian in the presence of the responsible government veterinarian. The inspection report required the farm owner, the fish disease veterinarian, and the state veterinarian to sign official compliance documents evaluating critical control points pertaining to the relevant regulations. The export facility registration was valid for 12 months and required annual reregistration. Included in the regulations was the contingency plan for notification and treatment of any new outbreaks of SVC and KHV. The contingency plan required destruction of infected stock and disinfection of affected ponds. In addition, recertification could only be reinstated after new stock on the farm had undergone the mandatory four tests over a 2-year period with negative results.

After the initial 2-year period with 6-monthly tests, the farm was able to meet EU import requirements for cyprinids as outlined in European Community Council Directive 2006/88/EC, providing the necessary guarantees for freedom from both Rhabdovirus carpio and KHV. The European Union Animal Health Certificate (EUHC), as per European Community Commission Decision 2006/656/EC, required that the farm be registered as an export facility. The export facility number, provided by the Department of Agriculture, Forestry, and Fisheries was issued by the Import and Export Policy Unit in the Directorate of Animal Health following inspection of the farm. Once all requirements had been met, the government veterinarian responsible for the farm completed the EUHC after inspecting each batch of fish for export.

\section{Discussion}

Koi have repeatedly been implicated in the international spread of KHVD (Pretto et al. 2013; Somga et al. 2010; Taylor et al. 2010). KHV has been included in the OIE Aquatic Animal Health Code (OIE 2015d), and certain European countries have recently amended their import requirements for koi to include guarantees for freedom from KHV.

Various strategies have been proposed to limit losses caused by KHV, including avoidance of exposure, particularly at shows; development of vaccines (Perelberg et al. 2005; Ronen et al. 2003); use of thermal temperature regimes (Ronen et al. 2003); selective breeding for increased resistance; and use of resistant hybrids in fish production (Hedrick et al. 2006). The recent implication of goldfish as potential asymptomatic carriers of KHV (Bergman et al. 2010; El-Matbouli et al. 2007; Sadler et al. 2008) should discourage simultaneous production of goldfish and koi and encourage separation of 
these two species in the marketplace. Use of thermal regimes and live attenuated vaccines has become controversial since the demonstration of a KHV carrier state (St-Hilaire et al. 2005; Eide et al. 2011). None of these measures addresses the risks posed by KHV-infected carrier fish in the spread of the disease. Immune competency to KHV following vaccination or survival of infection may result in reduced clinical disease but does not protect against the possibility of importing the disease with such fish.

Apparently vaccinated fish continue to be imported into South Africa. So-called KHV-tested fish are also marketed in South Africa. This is a tradedriven initiative whereby gill swabs from a small number of fish in a population have been tested by PCR with a negative result. Without sound statistical basis, the trader extrapolates the result as being representative of the population and uses this to provide assurances to customers. Such assurances are misleading and help to propagate the spread of the disease under the mistaken belief that sound biosecurity measures have been undertaken by the industry. Infected fish held outside of the permissive temperature range for disease, as well as recovered fish, are unlikely to reveal virus by standard PCR testing of gill swabs (Bergman et al. 2009) and require use of specialized sampling techniques (Eide et al. 2011).

To ensure freedom from KHV, known infected broodstock should be destroyed, and strict biosecurity and surveillance measures for the propagation of certified disease-free fish should be implemented. Application of a biosecurity program, based on the standardized approach used over many years to certify the disease-free status of salmonid ova exported from South Africa and reflected in the approach of the IAVBC (Palic et al. 2015), has in the case of this farm resulted in freedom from KHV. KHV is unlikely to have persisted on the farm in view of the measures taken: removal of all affected groups of fish; disinfection of ponds, ova, and equipment; segregation of fish with differing epidemiological status; a closed water supply; repeated testing of fish at statistically significant levels; and continuous monitoring of the health status of the fish. Once the negative disease status on the farm was achieved, future serological surveillance of the broodfish for KHV may have reduced the need for sacrificial sampling methods.

Despite limited diagnostic capabilities available from laboratories in South Africa at the time, the entrepreneurial opportunity of producing KHVfree fish has resulted in this breeder in South Africa achieving export certification for the EU market and preferential access to the local market for a number of years. In 2010 the owner decided to sell the game farm on which he had developed the koi breeding establishment. The broodstock were moved to a new facility on a farm close to the escarpment of the eastern Highveld of the Mpumalanga Province of South Africa. Water for the new ponds was sourced from a mountain stream originating in a commercial forested area. The water source was considered a risk factor, but wild carp populations were absent from this river, and high waterfalls above and 
below the farm acted as barriers to fish migration. The export of fish was suspended, but 6-monthly surveillance testing continued. The same biosecurity measures were applied to the new operation, and the farm was successfully registered as an export facility. Reduced local and international demand for koi fingerlings and a change in economic interests by the owner resulted in cessation of surveillance testing and export in 2013.

\section{Acknowledgments}

The authors would like to acknowledge the owners of Eden Fisheries, Mr. J. P. Roets and Mr. A. Roets, of Nelspruit, Mpumalanga, South Africa.

\section{References}

Aoki, T., I. Hirono, K. Kurokawa, H. Fukuda, R. Nahary, A. Eldar, A. J. Davison, T. B. Waltzek, H. Bercovier, and R. P. Hedrick. 2007. Genome sequences of three koi herpesvirus isolates representing the expanding distribution of an emerging disease threatening koi and common carp worldwide. Journal of Virology 81:5058-5065. doi:10.1128/JVI.00146-07

Bergman, S. M., J. Kempter, J. Sadowski, and D. Fichtner. 2006. First detection and isolation of koi herpesvirus (KHV) in cultured common carp (Cyprinus carpio L.) in Poland. Bulletin of the European Association of Fish Pathologists 26:97-104.

Bergman, S. M., P. Lutze, H. Shütze, M. Fisher, M. Dauber, D. Fichtner, and J. Kempter. 2010. Goldfish (Carassius auratus) is a susceptible species for koi herpesvirus (KHV) but not for KHV disease (KHVD). Bulletin of the European Association of Fish Pathologists 30:74-84.

Bergman, S. M., H. Shütze, U. Fischer, D. Fichtner, M. Riechardt, K. Meyer, D. Schrudde, and J. Kempter. 2009. Detection of koi herpesvirus (KHV) genome in apparently healthy fish. Bulletin of the European Association of Fish Pathologists 29:145-152.

Bretzinger, A., T. Fischer-Scherl, M. Oumouna, R. Hoffmann, and U. Truyen. 1999. Mass mortalities in koi carp, Cyprinus carpio, associated with gill and skin disease. Bulletin of the European Association of Fish Pathologists 19:177-185.

Cheng, L., C.-Y. Chen, M.-A. Tsai, P.-C. Wang, J.-P. Hsu, R.-S. Chern, and S.-C. Chen. 2011. Koi herpesvirus epizootic in cultured carp and koi, Cyprinus carpio L., in Taiwan. Journal of Fish Diseases 34:547-554. doi:10.1111/ j.1365-2761.2011.01266.x

Eide, K. E., T. Miller-Morgan, J. R. Heidel, M. L. Kent, R. J. Bildfell, S. LaPatra, G. Watson, and L. Jin. 2011. Investigation of koi herpesvirus latency in koi. Journal of Virology 85:4954-4962. doi:10.1128/JVI.01384-10

El-Matbouli, M., M. Saleh, and H. Soliman. 2007. Detection of cyprinid herpesvirus type 3 in goldfish cohabiting with CyHV-3-infected koi carp (Cyprinus carpio koi). Veterinary Record 161:792-793. 
Hedrick, R. P., T. B. Waltzek, and T. S. McDowell. 2006. Susceptibility of koi carp, common carp, goldfish, and goldfish $\times$ common carp hybrids to cyprinid herpesvirus-2 and herpesvirus-3. Journal of Aquatic Animal Health 18:26-34. doi:10.1577/H05-028.1

Kurita, J., K. Yuasa, T. Ito, M. Sano, R. P. Hedrick, M. Y. Engelsma, O. L. M. Haenen, et al. 2009. Molecular epidemiology of koi herpesvirus. Fish Pathology 44:59-66. doi: $10.3147 /$ jsfp. 44.59

OIE (World Organisation for Animal Health). 2015a. World Animal Health Information Database (WAHID). http://www.oie.int/wahis_2/public/wahid. $\mathrm{php} /$ Diseaseinformation/Diseasedistributionmap

OIE (World Organisation for Animal Health). 2015b. Koi Herpesvirus. In Manual of Diagnostic Tests for Aquatic Animals, Chapter 2.3.6. http://www.oie.int/ fileadmin/Home/eng/Health_standards/aahm/current/2.3.06_KHVD.pdf

OIE (World Organisation for Animal Health). 2015c. Aquatic Animal Health Surveillance. Manual of Diagnostic Tests for Aquatic Animals, Chapter 1.4. http:// www.oie.int/fileadmin/Home/eng/Health_standards/aahc/2010/chapitre_ aqua_ani_surveillance.pdf.

OIE (World Organisation for Animal Health). 2015d. Aquatic Animal Health Code. http://www.oie.int/international-standard-setting/aquatic-code/access-online/

Palić, D., A. D. Scarfe, and C. I. Walster. 2015. A standardized approach for meeting national and international aquaculture biosecurity requirements for preventing, controlling and eradicating infectious diseases. Journal of Applied Aquaculture. 27:185-219.

Perelberg, A., A. Ronen, M. Hutoran, Y. Smith, and M. Kotler. 2005. Protection of cultured Cyprinus carpio against a lethal viral disease by an attenuated virus vaccine. Vaccine 23:3396-3403. doi:10.1016/j.vaccine.2005.01.096

Pokorova, D., T. Vesely, V. Piackova, S. Reschova, and J. Hulova. 2005. Current knowledge on koi herpesvirus (KHV): A review. Veterinarni Medicina 50:139-147.

Pretto, T., A. Manfrin, C. Ceolin, M. Dalla Pozza, S. Zelco, R. Quartesan, M. Abbadi, V. Panzarin, and A. Toffan. 2013. First isolation of koi herpes virus (KHV) in Italy from imported koi (Cyprinus carpio koi). Bulletin of the European Association of Fish Pathologists 33:126-133.

Ronen, A., A. Perelberg, J. Abramowitz, M. Hutoran, S. Tinman, I. Bejerano, M. Steinitz, and M. Kotler. 2003. Efficient vaccine against the virus causing a lethal disease in cultured Cyprinus carpio. Vaccine 21:4677-4684. doi:10.1016/S0264-410X(03)00523-1

Sadler, J., E. Marecaux, and A. E. Goodwin. 2008. Detection of koi herpesvirus (CyHV-3) in goldfish, Carassius auratus (L.), exposed to infected koi. Journal of Fish Diseases 31:71-72. doi:10.1111/j.1365-2761.2007.00830.x

Sano, M., T. Ito, J. Kurita, T. Yanai, N. Watanabe, S. Miwa, and T. Iida. 2004. First detection of koi herpesvirus in cultured common carp Cyprinus carpio in Japan. Fish Pathology 39: 165-167. doi:10.3147/jsfp.39.165

Somga, J. R., L. D. De La Peña, C. D. Sombito, M. G. Paner, V. S. Suarnaba, G. C. Capulos, P. I. Santa Maria, and G. L. Po. 2010. Koi herpesvirus-associated mortalities in quarantined koi carp in the Philippines. Bulletin of the European Association of Fish Pathologists 30:2-7. 
St-Hilaire, S., N. Beevers, C. Joiner, R. P. Hedrick, and K. Way. 2009. Antibody response of two populations of common carp, Cyprinus carpio L., exposed to koi herpesvirus. Journal of Fish Diseases 32:311-320. doi:10.1111/ j.1365-2761.2008.00993.x

St-Hilaire, S., N. Beevers, K. Way, R. M. Le Deuff, P. Martin, and C. Joiner. 2005. Reactivation of koi herpesvirus infections in common carp Cyprinus carpio. Diseases of Aquatic Organisms 67:15-23. doi:10.3354/dao067015

Sunarto, A., R. Taukhid, A. Rukyani, I. Koesharyani, H. Supriyadi, L. Gardenia, H. Huminto, et al. 2005. Field investigations on a serious disease outbreak of koi and common carp (Cyprinus carpio) in Indonesia. In Diseases in Asian aquaculture $V$, ed. P. Walker, R. Lester, and R. G. Bondad-Reantaso, 125-135. Manila, Philippines: Fish Health Section, Asian Fisheries Society.

Taylor, N. G. H., P. F. Dixon, K. R. Jeffery, E. J. Peeler, K. L. Denham, and K. Way. 2010. Koi herpesvirus: Distribution and prospects for control in England and Wales. Journal of Fish Diseases 33:221-230. doi:10.1111/j.13652761.2009.01111.x

Walster, C. I. 1999. Clinical observations of severe mortalities in koi carp, Cyprinus carpio, with gill disease. Fish Veterinary Journal 3:54-58.

Way, K. 2004. Koi herpesvirus-A threat to wild carp. CEFAS Weymouth Laboratory Trout News 38:32-34. 